Ismail, S., Loganathan, N., Streimikiene, D., Mardani, A., \& Endut, W. A. (2018).

Influencing factors mitigate Middle East tourist travelling to Malaysia: The

quantile estimates. Journal of International Studies, 11(3), 137-146.

doi:10.14254/2071-8330.2018/11-3/12

\title{
Factors influencing the Middle East tourist travelling to Malaysia: The quantile estimates
}

\author{
Suraya Ismail \\ Faculty of Economics and Management Sciences \\ Universiti Sultan Zainal Abidin, Malaysia \\ surayaismai@unisza.edu.my \\ Nanthakumar Loganathan \\ Department of Business Administration \\ Azman Hashim International Business School \\ Universiti Teknologi Malaysia \\ Skudai, Johor, Malaysia \\ n4nantha@yahoo.com
}

Dalia Streimikiene

Lithuanian Sports University,

Kaunas, Lithuania

dalia@mail.lei.lt

\section{Tirta Nugraha Mursitama}

International Relations Department,

Bina Nusantara University, Jakarta, Indonesia tmursitama@binus.edu

\author{
Abbas Mardani \\ Department of Business Administration, \\ Ažman Hashim International Business School, \\ Universiti Teknologi Malaysia \\ Skudai, Johor, Malaysia \\ abbasmardani@yahoo.com

\section{Wan Anisah Endut} \\ Faculty of Economics and Management Sciences \\ Universiti Sultan Zainal Abidin \\ Malaysia \\ wanisah@unisza.edu.my
}

Abstract. This research examines the possible impacts of global oil prices, exchange rate and tourism prices on Malaysia's demand for the Middle East tourists' arrivals using monthly data covering the period from 1995 to 2017. We covered the 5 major sources of Middle East tourism to Malaysia in the last 2 decades, such as 
Saudi Arabia, Qatar, Iran, Syria and the United Arab Emirates. The estimates of the quantile regression reveal that the global oil price fluctuation has affected the Middle East tourist arrivals to Malaysia. First, we found that there is a positive quantile effect of tourism, domestic tourism prices and global oil prices with

DOI:

$10.14254 / 2071$ $8330.2018 / 11-3 / 12$

Middle East tourism demand in Malaysia throughout the estimated quantiles. Secondly, we could not find any specific influence of exchange rate and this shows that the fluctuating Malaysia's currency is not a major issue for the Middle East tourists. Overall, this finding can be useful for policymakers while improving their future tourism planning and in attracting more tourists to visit Malaysia in the upcoming years.

Keywords: Middle East, oil prices, quantile regression, real exchange rate, domestic tourism prices.

JEL Classification: E31, F31, Q4, Z32

\section{INTRODUCTION}

Changes in the world economic structure make tourism one of the most important sectors in Malaysia's economy. This sector becomes today the third contributing sector in Malaysia. It has also been recognized as one of the National Key Economic Areas (NKEA) in the government's vision of making Malaysia a highincome nation by 2020 . The country aims to attract 36 million tourists who will provide a return of USD 42 billion to the economy (Economic Planning Unit, 2018). The political environment, especially European one, make Malaysia a preferred tourist destination for Muslim tourists, especially those from the Middle East. Many efforts have been undertaken to increase the volume of tourist arrivals to Malaysia. For instance, collaborations with Middle Eastern airlines, Muslim-friendly packages and visa waiver programs. These and other efforts have led to Malaysia being crowned as the first rank and World's Top Muslim-friendly destination since 2015 till 2017 (Ministry of Tourism and Culture Malaysia, 2018). Tourism demand in general depends on various other variables too. This paper will discuss only three of those variables which are global oil prices, exchange rate and tourism prices that are believed to have a big impact on tourism demand.

The global oil prices with their impacts on airfares and other expenses have been recognized as one of the key factors influencing the tourism industry in 2017 (World Travel and Tourism Council, 2017). Changes in global oil prices will indirectly impact individual travel costs as well. An excessive increase in operating costs of airlines in 2008 due to changes in fuel prices caused the global aviation industry to record the losses of USD 5.2 billion that year (International Air Transport Association, 2008). The decreasing global oil supply which leads to higher oil prices does not only affect the countries that import oil but also affects the state of international tourism. However, studies on the tourist arrivals to New Zealand between 1996 until 2008 showed that changes in oil prices and fare costs had a weak significant impact on tourist arrivals to this country (Fominiene, 2016; Small \& Sweetman, 2009). This finding is in line with the study conducted by (Chaitip \& Chaiboonsri, 2009) who found that tourism demand has a positive relationship with the original country's GDP and negatively correlated with the exchange rate and oil prices. Meanwhile, Lennox (2012) and Roudi et al. (2018) found that oil prices are an important element in the tourism sector development.

Besides oil prices, the exchange rate is also an important factor for tourism development. Changes in the currency rates are seen to have an impact on the total international travel costs of individuals. There are few studies conducted on the relationship between exchange rates and tourism demand in Turkey (Agiomirgianakis et al., 2014; Akay, 2017; Özcan \& Uçak, 2016). Agiomirgianakis et al. (2014) found that 
exchange rate volatility is negatively associated with the tourist inflow to Turkey. Meanwhile, the research by (Kiliç \& Bayar, 2014) for the period between 1994 and 2013 have found the effective exchange rates to be positively related to tourism acceptance and travel expenditures in that particular country. However, this relationship is seen to exist only in the long run. The positive relationship of exchange rate with tourism in the long run is in line with Akay's (2017) findings. By using the Markov switching vector autoregressive model, Özcan and Uçak (2016) also agreed that income and the exchange rates have influenced the outbound travelling decisions.

Furthermore, Ibrahim (2011) has made a comparison of the exchange rate between the country of origin and the travel destination country in Egypt. He found that tourism in Egypt is very sensitive to price changes in which effective exchange rates does have a significant impact. Mahmood and Al-Khateeb (2017) found that Saudi Arabia's increase in currency rates could reduce the trade balance in all the sectors except construction and tourism. The significance of exchange rates and foreign tourist inflows into a country is also recognized by De Vita (2014). This is based on his research in 27 countries, both OECD members and non-OECD countries. Meanwhile, Borhan and Arsad (2016) study is in line with the findings by Ibrahim (2011) that tourism is very sensitive towards exchange rates. This is true as experienced by European tourists from Denmark, the UK and the Netherlands who are very sensitive to currency exchange rates. Tanjung et al. (2017) also agreed there is significant impact of exchange rate and real income on Indonesian outbound tourism to Malaysia. However, using the GARCH copula-based model, Tang et al. (2016) found that volatility in the currency exchange rate was not the determining factor for changes of international tourist inflows to China.

Tourism demand is also believed to be affected by tourism prices which are the integral part of tourist expenditures (Blagojevic Popovic, Nikic, Bulatovic \& Delibasic, 2018). There is a range of research studies on tourism prices and their trends (Jurigová \& Lencsésová, 2015; Pjerotic et al, 2017; Ruzic, \& Demonja, 2017; Serban et al, 2017; Serbin, \& Serbin, 2018; Tóth, 2016). One of them is Puah et al. (2014) who have investigated Malaysia's demand for tourism from Singapore. Their findings showed there is a negative relationship between tourism demand and tourism prices in this case. Habibi (2015) also examined the tourism demand from Iran to Malaysia. He analyzed the quarterly data from 2000 until 2013 using the autoregressive distributed lag (ARDL) model for several macroeconomic variables including Malaysia's tourism prices. The findings indicate that tourism demand has been influenced by tourism prices level. Utami et al. (2016) also compared Indonesia's tourism prices with Malaysia and Thailand, as these are the competing markets to some extent, using the almost ideal demand system (AIDS) model (Androniceanu, 2017). The authors concluded that the main factor influencing tourist expenditures in all three countries is tourism prices. Kim and Lee (2016) also explored the most significant factors for tourism demand to find that these would be relative prices (without transportation) and exchange rate. This conclusion has been formulated using the data on tourist arrivals from South Korea to Japan, from 2000: Q1 to 2014: Q4. Thus again, tourism price was found to be playing an important role in determining tourism demand.

The remainder of this paper is organized as follows. The next section presents the data and the estimation strategies focusing on conditional quantile regression. Section 3 provides the descriptive analysis and the empirical estimation results. Finally, Section 4 formulates the concluding remarks.

\section{DATA AND METHODOLOGY}

In this study, we attempt to explore the influence of tourism prices which proxied with the consumer price index $(C P I)$, global oil prices (Oii) and the domestic real effective exchange rate (Reer) with Middle East tourism demand in Malaysia. The Tour series represents the total numbers of Middle East country's tourist arrival in Malaysia, mainly from 5 major sources of countries (Saudi Arabia, Iran, Qatar, Syria and United 
Arab Emirates). We employ monthly time series dataset covering the period of 1995 (January) until 2017 (December). The Middle East tourism demand obtained from the Ministry of Tourism and Culture Malaysia (2018), while the tourism prices, global oil prices and real effective exchange rate are obtained from the Datastream Database. The following Eq. (1) and (2) explain the influence between the series used in this study with the expected sign.

$$
\begin{aligned}
& \text { Tour }_{t}=f\left(\text { CPI I }_{t}^{\text {m- }^{-}}, \text {Oil }_{t}^{\text {m+ }^{+}}, \text {Reer }_{t}^{\mathrm{m}_{-}},\right) \\
& \text {Tour }_{t}=\beta_{0}+\beta_{1} \text { CPI I }_{t}+\beta_{2} \text { Oil }_{t}+\beta_{3} \text { Reer }_{t}+\varepsilon_{t}
\end{aligned}
$$

where the CPI series are based on 2015 based year, and the global oil prices valued in USD currency. quantile analysis of all the series is illustrated graphically in Fig. 1. We found that, all series have a fluctuated varying pattern and not in a stable mode throughout the estimation period.
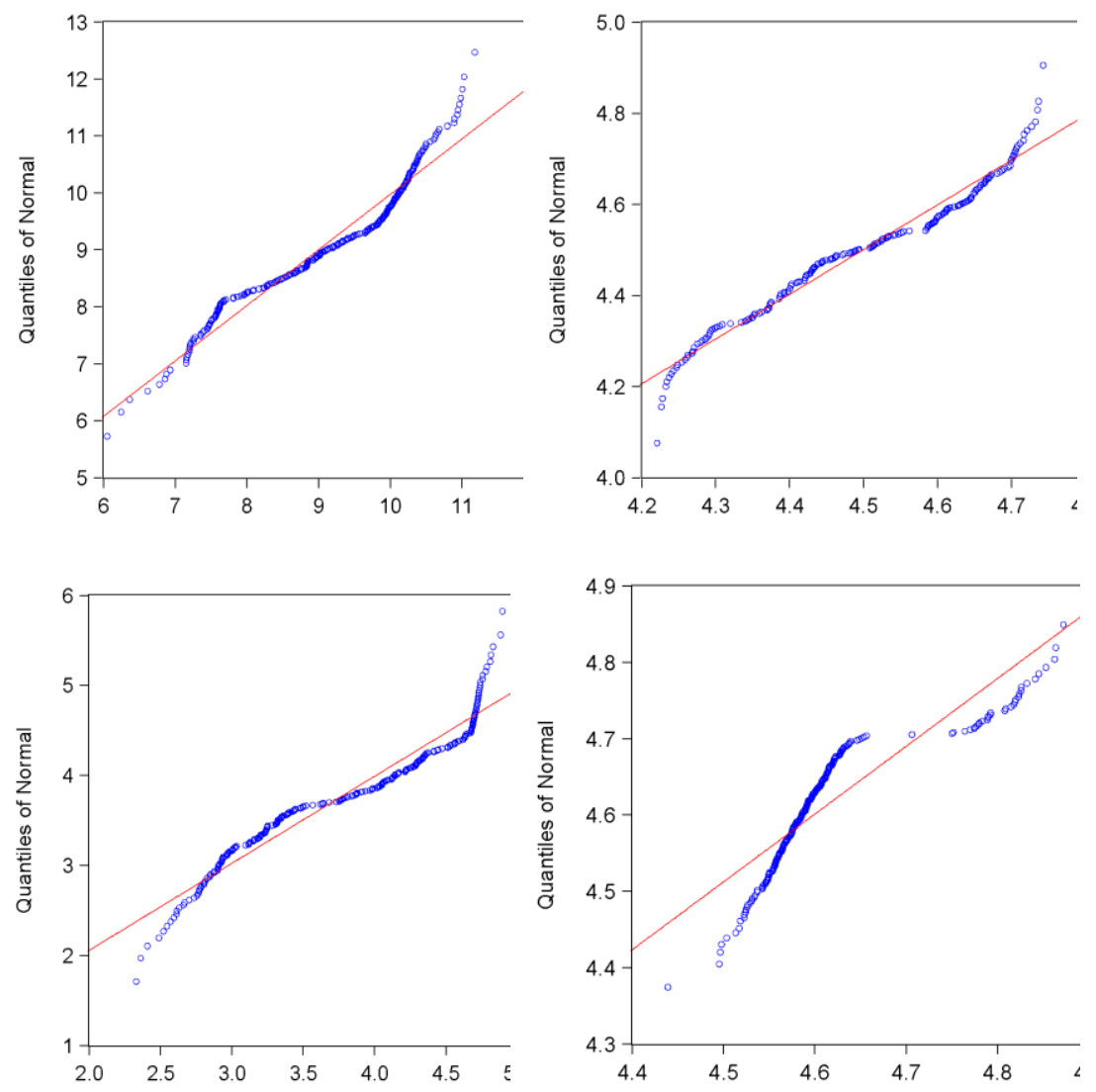

Figure 1. Q-Q plots for the estimating series in logarithm formation

Generally, most of the time series data will faced the non-stationary behaviors such as random walk, cycles and trend effects. This will cause a spurious indicating relationship between the series used in this study. Therefore, we employ the Augmented Dickey-Fuller (1981) (ADF); and Lee and Strazicich (2004) unit root tests to capture stationary condition. Later, we also employed the Koenker and Xiao's (2004) quantile unit root test, which allows differences in the transmission of all kinds of different quantiles effects and not depending with the deterministic trend effect. This test is more accurate, flexible and reduces the 
uncertainty estimation. The quantile unit root test is based on the following conditional quantile autoregression (AR) model in the Tour series:

$$
Q_{\text {Tour }_{t}}\left(\tau \mid F_{t}\right)=\alpha_{0}(\tau)+\alpha_{1}(\tau) \text { Tour }_{t-1}+\sum_{j=1}^{q} \quad \alpha_{j+1}(\tau) \Delta \text { Tour }_{t-1}
$$

where $Q_{\text {Tour }_{t}}\left(\tau \mid F_{t}\right)$ is the conditional quantile of Tour series to a level $r \in(0,1), F_{t}$ is the information accumulated up to the time frame of $t$, and the null hypothesis can be stated as $H_{0}: \alpha_{1}(\tau)=1$ for the given quantile $(\tau)$ of this study. Next, we extended the quantile unit root test with the quantile regression relationship between specified quantile of a dependent variable. With Tour as a dependent variable and CPI as the independent variable, the $\tau^{\text {th }}$ conditional quantile regression function can be expressed as follows:

$$
Q_{\text {Tour }}(\tau \mid C P I)=\inf \left\{b \mid F_{\text {Tour }}(C P I) \geq \tau\right\}=\sum_{k} \quad \beta_{k}(\tau) C P I_{k}=x^{\prime} \beta(\tau)
$$

where $F_{\text {Tour }}(C P I)$ is a conditional distribution function of Tour and $C P I$ series and the $\beta(\tau)$ represent the dependence relationship between both regressed series with specified quantiles $(\tau)$. In this study, we extend the existing literature by estimating the $\beta_{k}^{(\tau)}$ for a range of $\tau=0.25,0.50,0.75$ and 0.90 . Since we aimed to show the different effects of independent variables on the dependent variable across the spectrum, the specification quantile regression of this study can be written as follows:

$$
Q_{\text {Tour }_{t}}(\tau \mid X)=\alpha_{0}^{(\tau)}+\alpha_{1}^{(\tau)} C P I_{t}+\alpha_{2}^{(\tau)} \text { Oil }_{t}+\alpha_{3}^{(\tau)} \operatorname{Reer}_{t}+\epsilon_{t}^{(\tau)}
$$

\section{EMPIRICAL RESULTS}

The following Table 1 presents the overview of the summary statistics for the variables used in this study in natural logarithmic form. We found that, the Jarque-Bera (J-B) test rejected the null hypothesis of no normality for all series, indicating all series are not being a stable distribution condition. Based on the standard deviation result, the Tour series is the most volatile series, followed by the Oil series. Looking on the kurtosis coefficient, we found that all series facing coefficient below than 2 indicating there is no asymmetric effect arise.

Next we move on to the unit root tests. In this study we employ the ADF and the LS approaches. Table 2 shows the results of the tests at level and first differences forms. We found that, all test results for five series used in this study has archived stationary condition at first differences or $I(1)$ form. Furthermore, using the LS unit root test, we received 2 break dates within the series. For example, the Tour series faced a structural during the period of year 2000/June, and 2006/June which in line with global oil price crises worldwide. The global oil prices reached historic levels in 2005 and the forecasts underline an upward trend for up-coming years and this condition has reflected on the major tourism components, such as air and road transportation, and tourism industries linked with oil usage. Despite the fluctuating condition of gas and oil prices worldwide, the decline of the stock market and exchange rate in the globally in the late 1997 and year 2008 caused by the Asian financial crises and the global recession have proven the resilient due to the tourism receipts in Malaysia. 
Descriptive statistics in logarithm formation

\begin{tabular}{|l|c|c|c|c|}
\hline & Tour $_{t}$ & CPI $_{t}$ & Oil $_{t}$ & Reer $_{t}$ \\
\hline Mean & 9.092 & 4.490 & 3.764 & 4.611 \\
\hline Median & 9.271 & 4.473 & 3.828 & 4.591 \\
\hline Maximum & 11.181 & 4.743 & 4.896 & 4.872 \\
\hline Minimum & 6.052 & 4.220 & 2.329 & 4.439 \\
\hline Std. Dev. & 1.170 & 0.143 & 0.714 & 0.082 \\
\hline Skewness & -0.416 & -0.026 & -0.086 & 1.620 \\
\hline J-B $(p$-value $)$ & $0.000^{*}$ & $0.001^{*}$ & $0.000^{*}$ & $0.000^{*}$ \\
\hline
\end{tabular}

Note: * indicate the significance level at $1 \%$ level.

Based on the estimated results, we found that the CPI and Reer series capture the structural break condition ranged from 1998 until 2000. This implies that the estimated LS unit root test breaks are captured during the period when the country was facing the Asian financial crisis. Interestingly, the estimated LS unit root test for all series does not reject the null hypotheses at a level and with this evidence, we can accept both break dates provided in the following Table 2 .

Table 2

The ADF and LS unit root test results

\begin{tabular}{|c|c|c|c|c|c|}
\hline \multirow{2}{*}{} & \multicolumn{2}{|c|}{ ADF unit root } & \multicolumn{3}{c|}{ LS unit root } \\
\cline { 2 - 6 } & $I(0)$ & $I(1)$ & Stat. & $\mathrm{TB}_{1}$ & $\mathrm{~TB}_{2}$ \\
\hline Tour $_{t}$ & -1.317 & $-7.994^{*}$ & -4.707 & $2000 / \mathrm{June}$ & $2006 / \mathrm{June}$ \\
\hline CPI $_{t}$ & -3.138 & $-11.793^{*}$ & -4.840 & $1998 / \mathrm{Dec}$ & $2006 / \mathrm{Feb}$ \\
\hline Oil $_{t}$ & -1.284 & $-12.499^{*}$ & -3.858 & $1998 / \mathrm{July}$ & $2010 / \mathrm{Jan}$ \\
\hline Reer $_{t}$ & -2.262 & $-13.912^{*}$ & -5.260 & $1997 / \mathrm{June}$ & $1999 / \mathrm{Sept}$ \\
\hline
\end{tabular}

Note: * indicate the significance level at $1 \%$ level. The $I(0)$ and $I(1)$ represent the stationary level at level and first difference.

The results from the quantile unit root tests are reported in Table 3. We conduct the quantile unit root tests in the case of trend specification and the optimal lag selection are based on the AIC. The estimated quantile unit root test confirms that all variables lead to a temporary effect, adjust slowly at lower and middle quantile for most of the series. We found all series are stationary at $I(1)$, therefore we continue to perform the regression analysis. Table 4 displays the bootstrap quantile regression under different quantiles. The estimated quantile regression shows that; the tourism price has a positive effect on Middle East tourism demand throughout the estimated quantiles. Surprisingly, this result is not in line with most of previous study conducted related to Malaysia tourism, such as Loganathan et al. (2012), and Mohd Hanafiah and Mohd Harun (2010). We found there is a positive relationship between the global oil price increases and the tourism demand. Generally, this is an expected result, since the global oil price increases will mainly have a positive effect for the Middle East countries; income levels and thus, for their purchasing power globally. The third series, which is the Reer series, did not influence much on tourism demand, except in the early 0.25 quantile with a negative effect. 
The quantile unit root test results

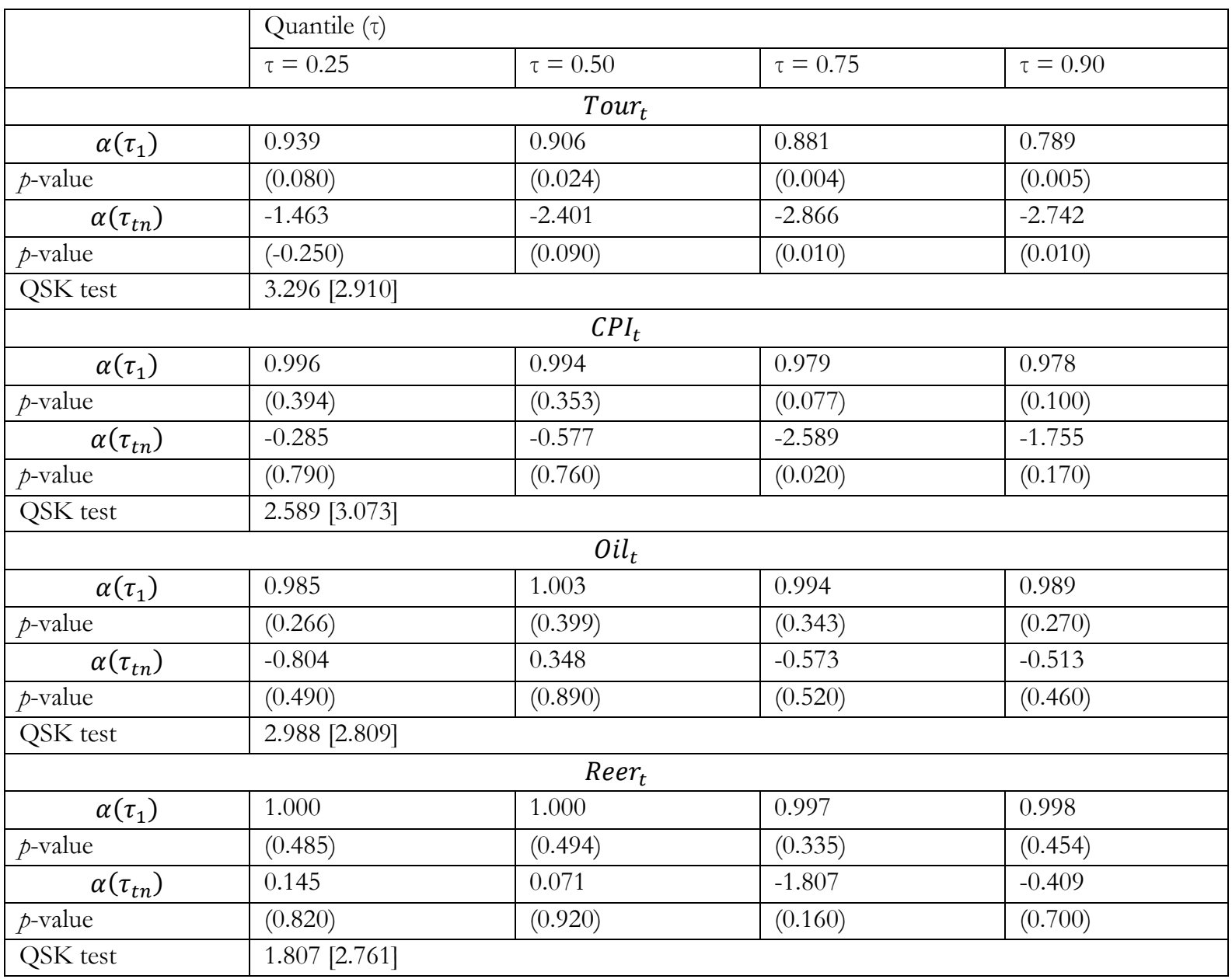

Note: QKS denotes the Kolmogorov-Smirvov test type proposed by Konker and Xiao (2004). The numbers in [] are p-values for the corresponding tests.

Table 4

The bootstrap quantile regression results

\begin{tabular}{|c|c|c|c|c|}
\hline & $\tau=0.25$ & $\tau=0.50$ & $\tau=0.75$ & $\tau=0.90$ \\
\hline CPI $t$ & $4.604^{*}$ & $4.314^{*}$ & $3.595^{*}$ & $1.729^{*}$ \\
& $(0.494)$ & $(0.543)$ & $(0.801)$ & $(0.642)$ \\
\hline Oil $l_{t}$ & $0.599^{*}$ & $0.610^{*}$ & 0.588 & $0.792^{*}$ \\
& $(0.096)$ & $(0.121)$ & $(0.147)$ & $(0.147)$ \\
\hline Reer $_{t}$ & $-0.814^{* * *}$ & -0.006 & -0.761 & $(1.810)$ \\
& $(0.417)$ & $(0.991)$ & $(1.221)$ & 0.312 \\
\hline Preudo R & 0.620 & 0.573 & 0.444 & 85.681 \\
\hline Quasi LR-stat & 523.924 & 454.575 & 223.902 & \\
\hline
\end{tabular}

Note: *, and *** indicate significance level at 1, 5 and 10\% level, respectively. Values in ( ) represent standard deviation. 
This can be illustrated using the quantile process estimates shown in Fig. 2. Based on Fig. 2, we realize that, the tourism price effects are sharply decreasing with the estimate quantiles. This clearly indicates that the Middle East tourism is becoming more sensitive to domestic price level. While the global oil prices have fluctuated over time and this is not a surprising indication, since we realize that the global oil prices are also fluctuated because of several reasons, especially the political stability among the oil producing countries attached with OPEC.
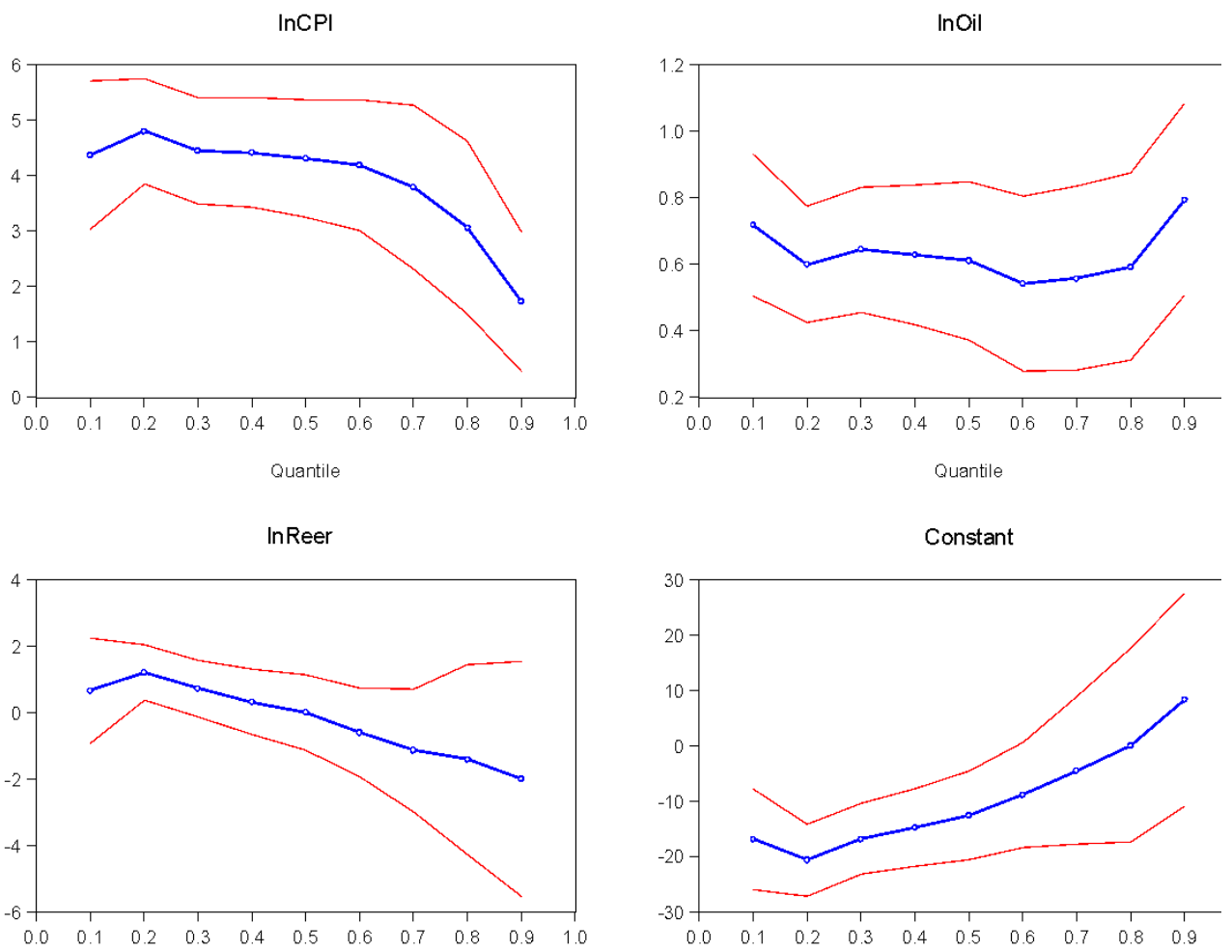

Figure 2. Quantile process estimates

\section{CONCLUSION}

The overall results of this study proved that the tourism prices are getting important for the Middle East countries tourism demand in Malaysia. There are obvious results showing that global oil prices also played an important role throughout the estimated quantiles, since the 6 countries involved in this study are all oil-exporting countries. This study has proven that oil price fluctuations, followed by the domestic tourism price and monetary policy has influenced the Middle East tourists' flows to Malaysia, even though we can also find some seasonal effects of tourism demand in the middle of the year for the entire range of the dataset. Therefore, policymakers in Malaysia should take into consideration this aspect so that to ensure the continuously increasing flows of the Middle East tourist arrivals in the upcoming years. In addition, we also note that arrivals of the Middle East tourists fall heavily on the months from June til August and this is quite interesting to be considered for future tourism planning and more specifically - for the Visit Malaysia Year 2020. Therefore, the government overall and all tourism-related agencies should take into consideration this and other policies-oriented studies on the dynamic nexus between domestic tourism 
prices, monetary policy and global oil price instability so that to boost the Middle East countries' sustainable tourism demand in the upcoming years in Malaysia.

\section{ACKNOWLEDGEMENT}

This paper has been successfully presented at the International Conference on Empirical Economics \& Social Sciences (ICEESS), 27-28 $8^{\text {th }}$ June 2018 in Bandirma, Turkey, and this research was funded under the Research Acculturation Grant Scheme (RAGS), Ministry of Higher Education of Malaysia (Vote. No. RAGS/1/2015/SS0/UNISZA/03/1).

\section{REFERENCES}

Agiomirgianakis, G., Serenis, D., \& Tsounis, N. (2014). Exchange Rate Volatility and Tourist Flows into Turkey. Journal of Economic Integration, 29(4), 700-725.

Akay, G. H., Cifter, A., \& Teke, O. (2017). Turkish Tourism, Exchange Rates and Income. Tourism Economics, 23(1), 66-77.

Androniceanu, A. (2017). The three-dimensional approach of Total Quality Management, an essential strategic option for business excellence. Amfiteatru Economic, 19(44), 61-78.

Fominiene, V. B. (2016). The Importance of Tourism Websites to Tourism Services And Assurance Of Their Competitiveness. Montenegrin Journal of Economics, 12(4), 41-51.

Blagojevic Popovic, O., Nikic, V., Bulatovic, I. \& Delibasic, M. (2018). Modeling Perceived Quality, Customer Satisfaction and Probability of Guest Returning to the Destination. Montenegrin Journal of Economics, 14(1), 6978.

Borhan, N \& Arsad, Z. (2016). Determining Factors Affecting Tourism Demand for Malaysia Using ARDL Modeling: A Case of Europe Countries. AIP Conference Proceeding, 1782(2). doi: doi.org/10.1063/1.4966095.

Chaitip, P., \& Chaiboonsri, C. (2009). A Panel Cointegration Analysis: Thailand's International Tourism Demand Model. Annals of the University of Petrosan Economics, 9(1), 129-142.

De Vita, G. (2014). The Long-run Impact of Exchange Rate Regimes on International Tourism Flows. Tourism Management, 45, 226-233.

Dickey, D.A., \& Fuller, W.A. (1981). Likelihood Ratio Statistics for Autoregressive Time Series with A Unit Root. Econometrica, 49, 1057-1072

Economic Planning Unit. (2018). Retrieved from http://www.epu.gov.my/

Habibi, F. (2015). Iranian Tourism Demand for Malaysia: A Bound Test Approach. Iranian Economic Review, 19(1), 6380.

International Air Transport Association. (2008). Traffic Slowdown Continues-Asia Leads August Decline. Press Release. September 2008. Retrieved from http://www.iata.org/

Ibrahim, M. A. (2011). The Determinants of International Tourism Demand for Egypt: Panel Data Evidence. European Journal of Economics, Finance and Administrative Sciences, 30, 50-58.

Jurigová, Z., \& Lencsésová, Z. (2015). Monitoring system of sustainable development in cultural and mountain tourism destinations. Journal of Competitiveness, 7(1), 35-52. doi:10.7441/joc.2015.01.03

Kiliç, C., \& Bayar, Y. (2014). Effects of Real Exchange Rate Volatility on Tourism Receipts and Expenditures in Turkey. Advances in Management and Applied Economics, 4(1), 89-101.

Kim, J., \& Lee, C. K. (2016). Role of Tourism Price in Attracting International Tourists: The Case of Japanese Inbound Tourism from South Korea. Journal of Destination Marketing \& Management, 6(1), 76-83.

Koenker, R., \& Xiao, Z. (2004). Unit Root Quantile Autoregression Inference. Journal of American Statistical Association, 99, 775-787.

Lee, J., \& Strazicich, M. (2004). Minimum LM Unit Root Test with One Structural Break. Working Paper No. 04-17, Department of Economics, Appalachian State University.

Lennox, J. (2012). Impacts of High Oil Prices on Tourism in New Zealand. Tourism Economics, 18(4), 781-800.

Loganathan, N., Subramaniam, T. \& Kogid, M. (2012). Is Malaysia Truly Asia? Forecasting Tourism Demand from ASEAN using SARIMA Approach. TOURISMOS, 7(1), 367-381. 
Mohd Hanafiah, M. H. \& Mohd Harun, M. F. (2010). Tourism Demand in Malaysia: A Cross-Sectional pool timeseries analysis. International Journal of Trade, Economics and Finance, 1(1), 80-83.

Mahmood, H. \& Al-Khateeb, T. Y. T. (2017). Testing Asymmetric Effect of Exchange Rate on Saudi Service Sector Trade: A Non-Linear ARDL Approach. International Journal of Economics and Financial Issues, 7(1), 73-77.

Ministry of Tourism and Culture Malaysia. (2018). Achievements and Recognitions. Retrieved from http://www.motac.gov.my/

Özcan, C. C., \& Uçak, H. (2016). Outbound Tourism Demand of Turkey: A Markov Switching Vector Autoregressive Approach. Czech Journal of Tourism, 5(2), 59-72.

Pjerotic, L., Delibasic, M., Joksiene, I., Griesiene, I., \& Georgeta, C. P. (2017). Sustainable tourism development in the rural areas. Transformation in Business \& Economics, 16(3), 21-30.

Ruzic, P., \& Demonja, D. (2017). Economic impacts of rural tourism in rural areas of Istria (Croatia). Transformation in Business \& Economics, 16(3). 31-41.

Puah, C. H., Thien, F. T., \& Arip, M. A. (2014). Singaporean Demand for Tourism in Malaysia. Economic Annals-XXI, $11 / 12,32-36$.

Serban, A. C., Aceleanu, M. I., \& Saseanu, A. S. (2017). Constraints of transition to ecological agriculture in a sustainable development society. Romanian perspective. Transformation in Business \& Economics, 16(3), 56-73.

Serbin, S., \& Serbin, A. (2018). Bromic Heating Co business exposure project to the Chile market. Economics, Management and Sustainability, 3(1), 79-93. doi:10.14254/jems.2018.3-1.8.

Small, J. \& Sweetman, C. (2009). New Zealand Tourist Arrivals. Covec Research Report. Retrieved from http://www.lincoln.ac.nz/

Tang, J., Sriboonchitta, S., Ramos, V., \& Wong, W. K. (2016). Modelling Dependence Between Tourism Demand and Exchange Rate Using the Copula-Based GARCH Model. Current Issues in Tourism, 19(9), 876-894.

Tanjung, A. F., Thien, F. T., Puah, C. H., Brahmana, R. K., \& Sianturi, R. H. (2017). Macroeconomic Determinants of Indonesian Tourism Demand in Malaysia. Advanced Science Letters, 23(4), 3159-3162.

Tóth, A. T. (2016). The Impact of the Hotel Industry on the Competitiveness of Tourism Destinations in Hungary. Journal of Competitiveness, 8(4), 85-104. doi: 10.7441/joc.2016.04.06

Utami, R. C., Hartono, D. H., \& Awirya, A. A. (2016). Analysis of The Competitiveness of Indonesia Tourism Price Compared to the Competitors (Demand Elasticity Approach). Jurnal Ekonomi Pembangunan: Kajian Masalah Ekonomi dan Pembangunan, 17(1), 108-124.

World Travel \& Tourism Council (2017). Travel \& Tourism: Global Economic Impact \& Issues 2017. Retrieved from http://www.wttc.org. 